\title{
PERBANDINGAN PERHITUNGAN STRUKTUR KUDA-KUDA BAJA SIKU GANDA DENGAN ASUMSI JOIN SEBAGAI SENDI DAN ASUMSI JOIN SEBAGAI JEPIT MENGGUNAKAN APLIKASI KOMPUTER
}

\author{
Herdy Dwiyana, Irika Widiasanti, Gina Bachtiar
}

\begin{abstract}
Abstrak
Berdasarkan identifikasi masalah maka peneliti membatasi masalah pada perbandingan hasil perhitungan desain kuda-kuda baja Pratt siku ganda dengan asumsi join sebagai sendi dan join sebagai jepit pada bentang $15 \mathrm{~m}, 18 \mathrm{~m}$ dan 21 m menggunakan aplikasi SAP 2000 student version.

Dengan karya tulis ini akan dicoba untuk mencari jawaban dari pertanyaan berikut ini Seberapa besarkah perbedaan nilai angka keamanan yang terjadi antara asumsi join sebagai sendi dengan asumsi join sebagai jepit pada struktur kudakuda baja Pratt siku ganda.

Hasil penelitian tentang perbandingan perhitungan struktur kuda-kuda baja siku ganda dengan asumsi join sebagai sendi dan join sebagai jepit menggunakan aplikasi komputer dapat memberikan informasi berupa nilai angka keamanan dan besar dimensi kuda-kuda yang diperlukan.
\end{abstract}

Herdy Dwiyana

Alumni Jurusan Teknik Sipil

Fakultas Teknik

Universitas Negeri Jakarta, 13220
Ir. Irika Widiasnti, MT

Staff Pengajar Jurusan Teknik Sipil

Fakultas Teknik

Universitas Negeri Jakarta, 13220 email : irika@ymail.com
Dr. Gina Bachtiar

Staff Pengajar Jurusan Teknik Sipil

Fakultas Teknik

Universitas Negeri Jakarta, 13220 email : ginbach@yahoo.com

\section{PENDAHULUAN}

Dewasa ini teknologi berkembang secara progresif dan membawa dampak besar terhadap peradaban manusia. Teknologi yang hadir merupakan inovasi dan penyempurnaan dari teknologi sebelumnya. Khususnya teknologi digital yang hadir dalam bentuk hadrware dan software yang sudah umum disebut komputer. Kolaborasi kedua piranti tersebut menjadikan suatu perangkat teknologi yang dapat membantu kita didalam memecahkan suatu masalah dengan tepat (efektif), detail dan menghabiskan waktu yang relatif singkat (efisien).

Program yang hadir saat ini, khususnya dalam disiplin ilmu teknik sipil sangatlah beraneka ragam. Salah satunya adalah SAP 2000, merupakan suatu program yang dirancang untuk 
analisa struktur. Bahkan SAP 2000 telah merilis versi yang dapat digunakan oleh mahasiswa (student version) untuk pembelajaran yang sifatnya nonkomersial. Kehadiran aplikasi komputer SAP 2000 student version menjadi kabar yang menggembirakan bagi kalangan akademisi di Indonesia khususnya mahasiswa. Hanya saja SAP 2000 student version memiliki keterbatasan jumlah titik join sebanyak 100 buah. Pada dasarnya keunggulan dan keunikan dari program ini adalah terletak pada analisa dan perancangan struktur baja dan beton. Dalam program ini juga telah disediakan beberapa template spesifikasi material baja dan beton. Template digunakan untuk mempercepat kita bekerja didalam program ini. Modifikasi terhadap template yang ada pada SAP 2000 student version tetap dapat dilakukan untuk menyelaraskan dengan kasus yang terjadi di lapangan.

Dewasa ini bangunan sudah banyak dirancang menggunakan bahan/material beton dan baja. Salah satu bangunan yang menggunakan bahan/material baja adalah struktur kudakuda baja siku ganda. Kuda-kuda merupakan suatu konstruksi yang terdiri dari rangkaian batang-batang yang tersusun sedemikian rupa-rupa sehingga mampu menahan beban diatasnya yakni beban atap, beban hujan, beban pekerja dan beban angin. Kuda-kuda dapat berbentuk segitiga, busur, trapesium dan lain sebagainya. Konstruksi rangka batang kuda-kuda ini dapat menahan beban atap sekalipun pada bentangan yang cukup besar.

Selama ini asumsi yang digunakan di dalam mendesain rangka batang adalah menggunakan asumsi bahwa pada setiap join dalam rangka batang merupakan join sendi. Pada join sendi di asumsikan bahwa perubahan bentuk dari sebarang batangnya tidak berpengaruh terhadap batang lain yang bertemu dan terikat kepadanya. Batang pada join sendi memungkinkan gerak berputar, dapat menerima gaya geser dan biasanya juga momen puntir, tetapi tidak untuk momen lentur.

Pada kenyataan yang terjadi di lapangan menunjukan asumsi yang digunakan selama ini dalam mendesain dinilai kurang tepat. Masalah yang timbul, suatu rangka batang yang disambung menggunakan plat buhul dengan baut lebih dari satu ataupun pengelasan batang pada plat buhul merupakan hubungan kaku yang tidak memungkinkan batang bergerak berputar (kondisi terjepit) dan akan timbul momen lentur pada join dan batang. 
Dalam penelitian ini, akan dibandingkan hasil perhitungan desain struktur kuda-kuda baja siku ganda menggunakan asumsi join sebagai sendi dengan asumsi join sebagai jepit. Hasil dari perbandingan perhitungan tersebut dapat dihasilkan suatu jawaban, yakni asumsi join manakah yang tepat digunakan dalam perhitungan desain struktur kuda-kuda baja siku ganda.

Berdasarkan latar belakang masalah di atas maka dapat diidentifikasikan beberapa masalah sebagai berikut, bagaimana pengaplikasian SAP 2000 student version untuk perhitungan struktur kuda-kuda baja, bagaimana proses perhitungan desain struktur kudakuda baja siku ganda dengan join sebagai sendi dalam aplikasi SAP 2000 student version, bagaimana proses perhitungan desain struktur kuda-kuda baja siku ganda dengan join sebagai jepit dalam aplikasi SAP 2000 student version, bagaimana cara membandingkan perhitungan join sebagai sendi dengan join sebagai jepit yang telah dianalisa dalam aplikasi SAP 2000 student version.

\section{METODA}

Struktur kuda-kuda baja siku ganda dengan asumsi join sebagai sendi perubahan bentuk dari sebarang batangnya tidak berpengaruh terhadap batang lain yang bertemu dan terikat kepadanya. Join sendi memungkinkan gerak berputar, dapat menerima gaya geser dan biasanya juga momen puntir, tetapi tidak untuk momen lentur. Berbeda dengan struktur kuda-kuda baja siku ganda dengan asumsi join sebagai jepit yakni batang-batang terlentur yang disambungkan kepadanya akan saling berinteraksi satu sama lain, atau dengan kata lain hubungan kaku di jepitan menularkan momen-momen dari suatu batang ke batang lain. Ketika struktur rangka mengalami perubahan bentuk, besar sudut diantara batangbatangnya tidak berubah.

Perhitungan desain struktur kuda-kuda baja siku ganda dengan membandingkan asumsi join yakni asumsi join sebagai sendi dan asumsi join sebagai jepit akan menghasilkan nilai gaya aksial yang berbeda. Gaya aksial tersebut diverifikasi menggunakan SNI-03-1729- 
2002 tentang Tata cara perencanaan struktur baja untuk bangunan gedung sehingga dapat diketahui nilai angka keamanannya.

Perhitungan desain struktur kuda-kuda baja siku ganda dengan asumsi join sebagai sendi dan join sebagai jepit dalam rangka mendapatkan nilai gaya aksial batang dan momen lentur dibantu dengan aplikasi komputer SAP 2000 student version. Penggunaan aplikasi sap 2000 student version dalam perbandingan perhitungan struktur kuda-kuda baja siku ganda dengan asumsi join sebagai sendi dan join sebagai jepit dikarenakan aplikasi tersebut memiliki tingkat kevaliditasan yang baik, sehingga diharapkan akan menghasilkan data-data output yang lebih optimal.

\section{Menentukan Data Penelitian}

Data - data penelitian yang ditentukan adalah sebagai berikut :

1. Kemiringan atap $25^{\circ}$.

2. Jarak antar kuda-kuda, $L_{a k k b}=5 \mathrm{~m}$.

3. Jarak antar gordeng, $L_{a g}=1,66 \mathrm{~m}$.

4. Bentang kuda-kuda, $L_{k k}=(15 \mathrm{~m}, 18 \mathrm{~m}$ dan $21 \mathrm{~m})$.

5. Penutup atap menggunakan seng gelombang, $W_{a t p}=10 \mathrm{~kg} / \mathrm{m}^{2}$.

6. Gordeng menggunakan profil canal $14, W_{\text {grd }}=16 \mathrm{~kg} / \mathrm{m}^{2}$

7. Diasumsikan menggunakan profil 2L70.70.7-8 pada rangka kuda-kuda. Menggunakan mutu baja BJ 37 , dengan $f_{y}=240 \mathrm{MPa}, f_{u}=370 \mathrm{MPa}, \mathrm{E}=$ 200.000 MPa, $\mathrm{G}=80.000 \mathrm{MPa}, \mu=0,3$ dan koefisien pemuaian $(\alpha)=12 \mathrm{E}-6 /{ }^{\circ} \mathrm{C}$.

\section{Perhitungan Pembebanan Pada Struktur Rangka Kuda-Kuda}

Beban yang digunakan dalam perhitungan struktur kuda-kuda baja adalah beban mati, beban hidup dan beban angin. Beban mati terdiri dari berat dari penutup atap seng gelombang, berat gording dengan profil baja canal, berat profil baja siku ganda dan berat plafond eternit termasuk rangka dan rusuknya. Beban hidup terdiri dari beban hidup akibat hujan dan beban hidup akibat orang/pekerja. Beban angin terdiri dari tekanan angin positif 
dan tekanan angin negatif. Besarnya nilai beban-beban tersebut didasarkan pada Peraturan Pembebanan Indonesia untuk Gedung (1983) dan Tabel Profil Baja. Rincian perhitungan pembebanan pada struktur rangka kuda-kuda adalah sebagai berikut :

1) Beban Mati

- Berat penutup atap seng gelombang, $W_{\text {atp }}=10 \mathrm{~kg} / \mathrm{m}^{2}$

- Berat gordeng canal $14, W_{\text {grd }}=16 \mathrm{~kg} / \mathrm{m}^{2}$

- Berat sendiri rangka kuda-kuda dihitung secara otomatis pada aplikasi SAP 2000 student version dengan menentukan nilai self weight multiplier sebesar 1 (satu).

- Berat plafond eternit termasuk rangka dan rusuknya, $W_{p f n}=11 \mathrm{~kg} / \mathrm{m}^{2}$

Beban yang diletakkan pada struktur rangka kuda-kuda merupakan beban titik dengan satuan $\mathrm{kg}$ (kilogram). Perhitungan beban titik menggunakan konsep tributary loaded areas.

- Jarak antar kuda-kuda baja, $L_{a k k b}=5 \mathrm{~m}$

- Jarak antar gordeng, $L_{a g}=1,66 \mathrm{~m}$

- Luas pembebanan, $A_{t l a}=L_{a g} \cdot L_{a k k b}=1,66 \cdot 5=8,3 \mathrm{~m}^{2}$

Beban titik pada join didapat dari hasil perkalian berat per satuan luas dengan luas pembebanan (tributary loaded areas). Beban titik akibat beban mati yang terjadi adalah sebagai berikut :

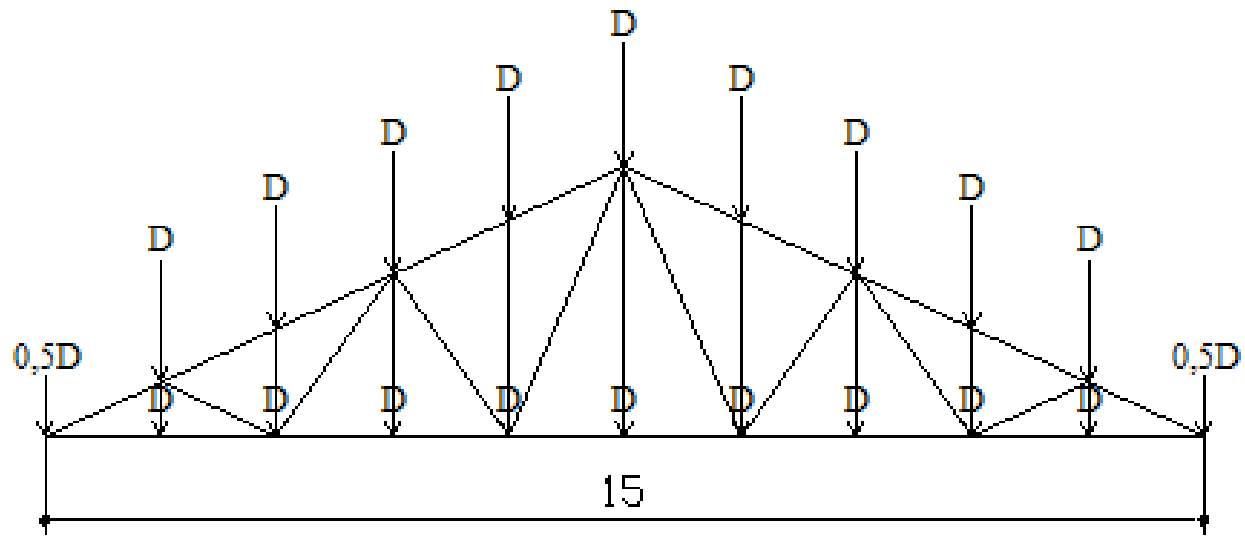

Gambar 1. Penempatan beban mati struktur kuda-kuda Pratt siku ganda

$\begin{array}{lll}P_{\text {atp }}=W_{\text {atp }} \cdot A_{\text {tla }} & =10 \mathrm{~kg} / \mathrm{m}^{2} \cdot 8,3 \mathrm{~m}^{2} & =83 \mathrm{~kg} \\ P_{\text {grd }}=W_{\text {grd }} \cdot A_{\text {tla }} & =16 \mathrm{~kg} / \mathrm{m}^{2} \cdot 8,3 \mathrm{~m}^{2} & =132,8 \mathrm{~kg}\end{array}$




$$
\begin{array}{lll}
P_{\text {pfn }}=W_{\text {pfn }} \cdot A_{\text {tla }} & =11 \mathrm{~kg} / \mathrm{m}^{2} \cdot 8,3 \mathrm{~m}^{2} & =91,3 \mathrm{~kg} \\
P_{1}=P_{\text {atp }}+P_{\text {grd }} & =83 \mathrm{~kg}+132,8 \mathrm{~kg} & =215,8 \mathrm{~kg} \\
0,5 P_{2}=0,5\left(P_{\text {atp }}+P_{\text {grd }}+P_{\text {pfn }}\right) & =0,5(83 \mathrm{~kg}+132,8 \mathrm{~kg}+91,3 \mathrm{~kg}) & =153,55 \mathrm{~kg}
\end{array}
$$

b) Beban Hidup

- Beban akibat air hujan, $W_{\text {ahj }}=20 \mathrm{~kg} / \mathrm{m}^{2}$

- Beban akibat pekerja/orang, $P_{p k j}=100$

Beban hidup pada atap diambil yang paling menentukan/paling besar diantara beban akibat air hujan dan beban akibat pekerja. Beban yang diletakkan pada struktur rangka kuda-kuda merupakan beban titik dengan satuan kg (kilogram). Perhitungan beban titik menggunakan konsep tributary loaded areas.

- Jarak antar kuda-kuda baja, $L_{a k k b}=5 \mathrm{~m}$

- Jarak antar gordeng, $L_{a g}=1,66 \mathrm{~m}$

Luas pembebanan, $A_{t l a}=L_{a g} \cdot L_{a k k b}=1,66 \cdot 5=8,3 \mathrm{~m}^{2}$

Beban titik pada join didapat dari hasil perkalian berat per satuan luas dengan luas pembebanan (tributary loaded areas). Beban titik akibat beban hidup yang terjadi adalah sebagai berikut :

$$
\begin{aligned}
& P_{\text {ahj }}=W_{\text {ahj }} \cdot A_{\text {tla }}=20 \mathrm{~kg} / \mathrm{m}^{2} \cdot 8,3 \mathrm{~m}^{2} \quad=166 \mathrm{~kg} \\
& P_{\text {pkj }}=100 \mathrm{~kg}
\end{aligned}
$$

Beban yang menentukan adalah beban akibat air hujan $P_{a h j}=166 \mathrm{~kg}$

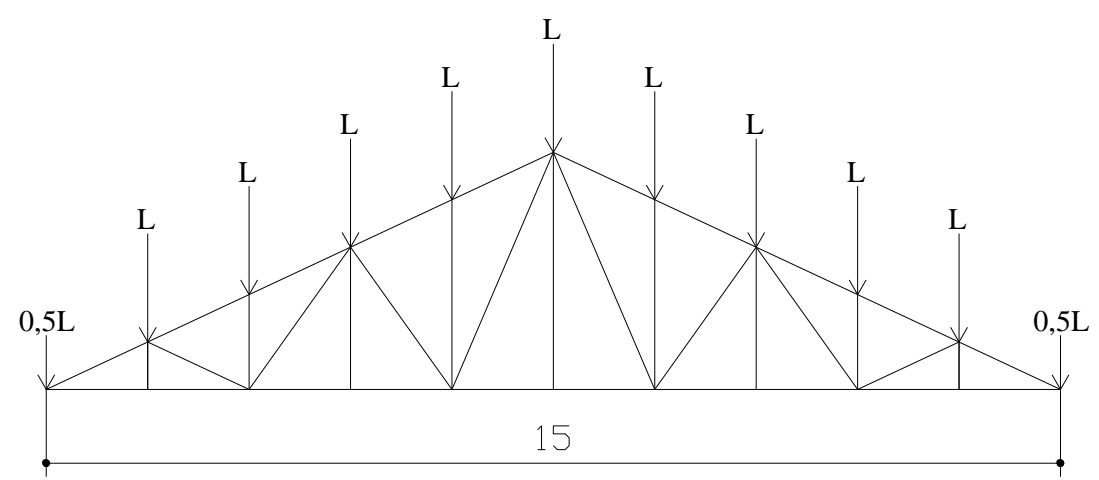

Gambar 2 Penempatan beban hidup struktur kuda-kuda baja Pratt siku ganda 
c) Beban Angin

- Beban akibat angin, $W_{\text {agn }}=40 \mathrm{~kg} / \mathrm{m}^{2}$

- Koefisien angin ditentukan berdasarkan rumus

Di pihak angin : $\quad a<65^{\circ}(0,02 a-0,4)$

$$
65^{0}<a<90^{0}(+0,9)
$$

Nilai koefisien di pihak angin (tekan) $=(0,02 a-0,4)=(0,02.25-0,4)=0,1$

Di belakang angin, untuk semua a $(-0,4)$

Nilai koefisien di belakang angin (hisap) $=-0,4$

Beban angin memberi tekanan merata dan hisapan merata pada penutup atap. Penutup atap dengan luasan tertentu meneruskan tekanan merata dan hisapan merata tersebut kepada gordeng. Sehingga beban yang diterima oleh kuda-kuda berupa beban titik. Perhitungan beban titik menggunakan konsep tributary loaded areas.

- Jarak antar kuda-kuda baja, $L_{a k k b}=5 \mathrm{~m}$

- Jarak antar gordeng, $L_{a g}=1,66 \mathrm{~m}$

Luas pembebanan, $A_{t l a}=L_{a g} \cdot L_{a k k b}=1,66 \cdot 5=8,3 \mathrm{~m}^{2}$

Beban titik pada join didapat dari hasil perkalian berat per satuan luas dengan luas pembebanan (tributary loaded areas). Beban titik bekerja tegak lurus terhadap garis sumbu batang. Beban titik akibat beban angin yang terjadi adalah sebagai berikut :

$$
\begin{array}{lll}
P_{\text {agnt }}=\mathrm{k}_{\text {at }} \cdot W_{\text {agn }} \cdot A_{t l a}=0,1 \cdot 40 \mathrm{~kg} / \mathrm{m}^{2} \cdot 8,3 \mathrm{~m}^{2} & =33,2 \mathrm{~kg} \\
P_{\text {agnh }} & =\mathrm{k}_{\text {ah }} \cdot W_{\text {agn }} \cdot A_{t l a}=-0,4 \cdot 40 \mathrm{~kg} / \mathrm{m}^{2} \cdot 8,3 \mathrm{~m}^{2} & =132,8 \mathrm{~kg} \\
P_{\text {agnt horizontal }}=\operatorname{Cos} 45^{0} \cdot P_{\text {agnt }}=0,707 \cdot 33,2 \mathrm{~kg} & =22,63 \mathrm{~kg} \\
P_{\text {agnt vertikal }}=\operatorname{Sin} 45^{0} \cdot P_{\text {agnt }}=0,707 \cdot 33,2 \mathrm{~kg} & =22,63 \mathrm{~kg} \\
P_{\text {agnh horizontal }}=\operatorname{Cos} 45^{0} \cdot P_{\text {agnh }}=0,707 \cdot 132,8 \mathrm{~kg} & =93,9 \mathrm{~kg} \\
P_{\text {agnh vertikal }}=\operatorname{Sin} 45^{0} \cdot P_{\text {agnh }}=0,707 \cdot 132,8 \mathrm{~kg} & =93,9 \mathrm{~kg} \\
P_{1} & =0,5 P_{\text {agnt horizontal }}+0,5 P_{\text {agnh horizontal }} & =58,69 \mathrm{~kg} \\
P_{2} & =0,5 P_{\text {agnt vertikal }}+0,5 P_{\text {agnh vertikal }} & =35,21 \mathrm{~kg}
\end{array}
$$




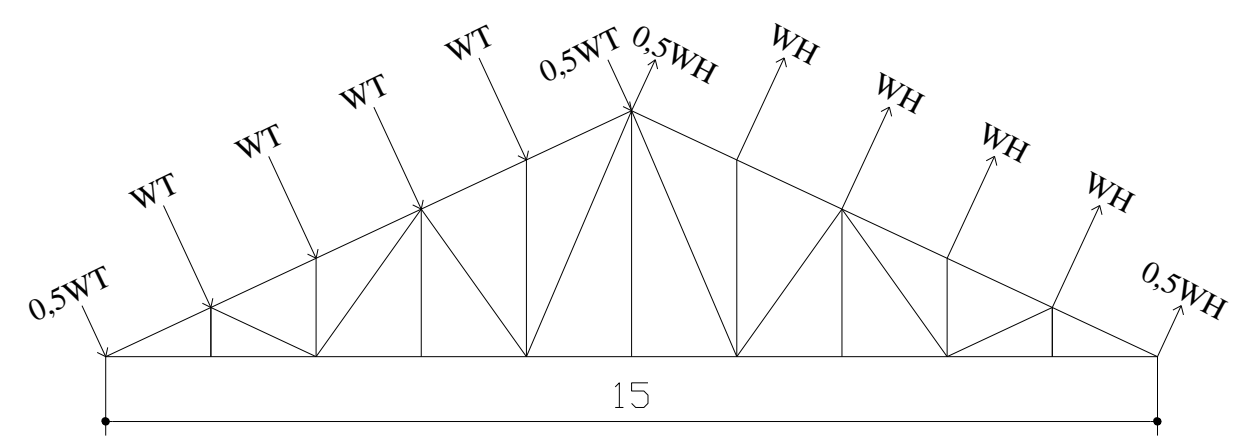

Gambar 3. Penempatan beban angin struktur kuda-kuda baja Pratt siku ganda

d) Kombinasi Pembebanan

Berdasarkan SNI-03-1729-2002 tentang Tata Cara Perencanaan Struktur Baja untuk Bangunan Gedung, beban yang bekerja pada struktur baja merupakan beban terfaktor. Kombinasi beban yang digunakan dalam perhitungan struktur kuda-kuda baja ada 6 (enam) kombinasi yaitu :

1) $1,4 \mathrm{D}$

2) $1,2 \mathrm{D}+0,5 \mathrm{H}$

3) $1,2 \mathrm{D}+1,6 \mathrm{H}+0,8 \mathrm{~W}$

4) $1,2 \mathrm{D}+1,3 \mathrm{~W}+0,5 \mathrm{H}$

5) $0,9 \mathrm{D}+1,3 \mathrm{~W}$

6) $0,9 \mathrm{D}-1,3 \mathrm{~W}$

Dengan,

$D$ = beban mati

$\mathrm{L}=$ beban hidup

$\mathrm{W}=$ beban angin

Perhitungan Struktur Kuda-Kuda Baja Pratt Siku Ganda dengan Asumsi Join Sebagai Sendi

a) Langkah Perhitungan Menggunakan Aplikasi SAP 2000 Student Version

1) Menentukan geometri model struktur kuda-kuda baja pratt siku ganda 
Penentuan geometri model struktur dalam aplikasi sap 2000 student version dilakukan setelah membuka file baru. Kuda-kuda baja Pratt siku ganda dengan bentang 15 meter memiliki Grid Spaces pada sumbu $x=10$, sumbu $y=0$ dan sumbu $z=1$ serta Grid Spacing pada sumbu $x=1,5 \mathrm{~m}, y=1 \mathrm{~m}$ dan sumbu $z=3,5$ m.

2) Menentukan join sendi pada struktur

Penentuan join pada struktur dilakukan setelah geometri model struktur ditentukan. Penentuan join sendi pada struktur kuda-kuda baja Pratt siku ganda dilakukan dengan me-release frame moment 33 (mayor).

3) Menentukan material dan section

Penentuan material dan section didasarkan pada SNI-03-1729-2002 tentang Tata Cara Perencanaan Struktur Baja untuk Bangunan Gedung dan Tabel Profil Baja. Ditentukan material dengan sifat mekanis baja (BJ 37, $f_{y}=240 \mathrm{Mpa}, E=200.000 \mathrm{MPa}$, $\mathrm{G}=80.000 \mathrm{MPa}, \mu=0,3$ dan koefisien pemuaian $\left.(\alpha)=12 \times 10^{-6} /{ }^{\circ} \mathrm{C}\right)$. Ditentukan section menggunakan profil 2L70.70.7-8.

4) Menentukan pembebanan yang digunakan

Beban yang digunakan dalam analisa struktur menggunakan aplikasi SAP 2000 student version adalah beban mati, beban hidup, beban angin yang berhembus dari kiri ke kanan struktur kuda-kuda dan beban angin yang berhembus dari kanan ke kiri struktur kuda-kuda baja. Penentuan pembebanan dalam aplikasi SAP 2000 student version dilakukan pada menu define static load cases. Khusus pada beban mati nilai self weighter multiplier diisi dengan nilai 1 (satu). Penentuan nilai angka 1 (satu) pada beban mati memiliki maksud yakni memberi perintah pada aplikasi SAP 2000 student version untuk menghitung berat sendiri kuda-kuda secara otomatis sesuai dengan section yang ditentukan. 
5) Menentukan kombinasi beban

Kombinasi beban ditentukan oleh SNI-03-1729-2002 tentang Tata Cara Perencanaan Struktur Baja untuk Bangunan Gedung. Penentuan kombinasi pembebanan dalam aplikasi SAP 2000 student version dapat dilihat pada Gambar 3.8. Kombinasi beban yang digunakan adalah sebagai berikut :

1) $1,4 \mathrm{D}$ (COMB1)

2) $1,2 \mathrm{D}+0,5 \mathrm{H}$ (COMB2)

3) $1,2 \mathrm{D}+1,6 \mathrm{H}+0,8 \mathrm{~W}$ (COMB3)

4) $1,2 \mathrm{D}+1,3 \mathrm{~W}+0,5 \mathrm{H}$ (COMB4)

5) $0,9 D+1,3 W$ (COMB5)

6) $0,9 \mathrm{D}-1,3 \mathrm{~W}$ (COMB6)

Dengan,

$\mathrm{D}=$ beban mati

$\mathrm{L}=$ beban hidup

$\mathrm{W}=$ beban angin

6) Menentukan pembebanan pada join

Beban yang bekerja pada join merupakan beban titik. Beban-beban tersebut berupa beban mati, beban hidup, beban angin kanan dan beban angin kiri.

Beban mati yang bekerja pada struktur kuda-kuda baja antara lain beban akibat berat penutup atap, beban akibat akibat berat gording, beban akibat berat sendiri struktur kuda-kuda baja dan berat plafond eternit termasuk rangka dan rusuk. Beban mati akibat berat penutup atap dan akibat berat gording diletakkan pada join batang atas. Sedangkan beban mati akibat plafond eternit termasuk rangka dan rusuk diletakkan pada join batang bawah.

Beban hidup yang bekerja pada struktur kuda-kuda baja adalah beban akibat air hujan dan beban akibat pekerja/orang. Beban tersebut diletakkan pada join batang atas.

Beban angin yang bekerja pada struktur kuda-kuda baja adalah beban akibat angin tekan dan angin hisap. Beban tersebut diletakkan pada join batang atas dan bekerja tegak lurus terhadap sumbu batang atas. Pada apikasi SAP 2000 student version 
tidak disediakan fitur yang dapat mengatur pembebanan tegak lurus terhadap bidang tertentu. Maka beban tersebut diurai menjadi 2 (dua) arah sumbu, yakni beban yang bekerja pada sumbu $\mathrm{x}$ (horizontal) dan beban yang bekerja pada sumbu z (vertikal).

\section{7) Analisa struktur}

Setelah melewati tahapan pembebanan pada join analisa struktur dapat dilakukan. Analisa struktur dilakukan pada frame $2 D$, hal ini disebabkan sumbu yang digunakan pada geometri model struktur adalah sumbu $x$ dan sumbu $z$.

\section{b) Tabulasi Nilai Gaya Aksial Terfaktor Batang}

Melalui proses analisa struktur menggunakan aplikasi SAP 2000 student version, nilai gaya aksial terfaktor batang dapat diketahui. Nilai gaya aksial terfaktor batang yang bekerja pada struktur kuda-kuda baja Pratt siku ganda join sendi terlampir pada Tabel $1 .$.

Isi dari tabulasi nilai gaya aksial adalah pengklasifikasikan batang menjadi 4 jenis yakni batang bawah, batang atas, batang vertikal dan batang diagonal. Termasuk juga pencantuman nilai gaya aksial tarik terfaktor dan gaya aksial tekan terfaktor maksimum yang bekerja pada batang. Hasil pentabulasian nilai gaya aksial terfaktor batang pada struktur kuda-kuda baja Pratt siku ganda bentang 15 meter terlihat dalam Tabel 1.

Tabel 1 Tabulasi nilai gaya aksial terfaktor kuda-kuda baja join sendi bentang 15 meter

\begin{tabular}{|l|l|l|l|l|l|}
\hline \multirow{2}{*}{ Klasifikasi Batang } & \multirow{2}{*}{$\begin{array}{l}\text { Label } \\
\text { Batang }\end{array}$} & \multicolumn{3}{|l|}{ Gaya Aksial Maksimum } & \multicolumn{2}{l|}{ Gaya Aksial Maksimum } \\
\cline { 3 - 6 } & & Tarik (+) kg & Tekan (-) kg & $\begin{array}{l}\text { Tarik } \\
\text { Akibat }\end{array}$ & $\begin{array}{l}\text { Tekan } \\
\text { Akibat }\end{array}$ \\
\hline Batang Bawah & 1 s.d. 10 & 7677,11 & $-983,55$ & COMB3 & ANGIN \\
\hline Batang Atas & 11 s.d. 20 & 596,90 & $-7993,26$ & ANGIN & COMB3 \\
\hline Batang Vertikal & 21 s.d. 29 & 344,30 & $-1836,17$ & ANGIN & COMB3 \\
\hline
\end{tabular}




\begin{tabular}{|l|l|l|l|l|l|} 
Batang Diagonal & 30 s.d. 37 & 2212,35 & $-374,59$ & COMB3 & ANGIN \\
\hline
\end{tabular}

c) Verifikasi Nilai Angka Keamanan Terhadap Gaya Aksial Tarik Terfaktor dan Aksial Tekan Terfaktor Batang

Tabel 2 Nilai angka keamanan struktur kuda-kuda baja Pratt siku ganda join sendi bentang $15 \mathrm{~m}$ terhadap gaya aksial

\begin{tabular}{|l|l|l|l|l|l|}
\hline No. & Join & $\begin{array}{l}\text { Bentang } \\
(\mathrm{m})\end{array}$ & Profil 2L & $\begin{array}{l}\text { Klasifikasi } \\
\text { Batang }\end{array}$ & $\begin{array}{l}\text { Nilai Angka } \\
\text { Kemanan }\end{array}$ \\
\hline 1. & Sendi & 15 & 70.70 .7 & Bawah & 0,20 \\
\hline 2. & Sendi & 15 & 70.70 .7 & Atas & 0,34 \\
\hline 3. & Sendi & 15 & 70.70 .7 & Vertikal & 0,19 \\
\hline 4. & Sendi & 15 & 70.70 .7 & Diagonal & 0,06 \\
\hline
\end{tabular}

Tabel 2 menunjukkan nilai angka keamanan yang telah diverifikasi dengan SNI-031729-2002 tentang Tata Cara Perencanaan Struktur Baja untuk Bangunan Gedung.

\section{Perhitungan Struktur Kuda-Kuda Baja Pratt Siku Ganda dengan Asumsi Join Sebagai Jepit}

a) Langkah Perhitungan Menggunakan Aplikasi SAP 2000 Student Version

Langkah perhitungan struktur kuda-kuda baja Pratt siku ganda asumsi join sebagai jepit dalam aplikasi SAP 2000 student version idem dengan langkah perhitungan struktur kuda-kuda baja Pratt siku ganda asumsi join sebagai sendi terkecuali pada penentuan join sebagai jepit. Penentuan join sebagai jepit dalam aplikasi SAP 2000 student version dilakukan dengan tidak me-release frame moment 33 (mayor).

\section{b) Tabulasi Nilai Gaya Aksial Terfaktor Batang}

Melalui proses analisa struktur menggunakan aplikasi SAP 2000 student version, nilai gaya aksial terfaktor batang dapat diketahui. Isi dari tabulasi nilai gaya aksial adalah pengklasifikasikan batang menjadi 4 jenis yakni batang bawah, batang atas, batang vertikal dan batang diagonal. Termasuk juga pencantuman nilai gaya aksial tarik terfaktor dan gaya aksial tekan terfaktor maksimum yang bekerja pada batang. 
Hasil pentabulasian nilai gaya aksial terfaktor batang pada struktur kuda-kuda baja Pratt siku ganda bentang 15 meter terlihat dalam Tabel 3.

Tabel 3 Tabulasi nilai gaya aksial terfaktor kuda-kuda baja join jepit bentang 15 meter

\begin{tabular}{|l|l|l|l|l|l|}
\hline \multirow{2}{*}{ Klasifikasi Batang } & \multirow{2}{*}{$\begin{array}{l}\text { Label } \\
\text { Batang }\end{array}$} & \multicolumn{2}{|l|}{ Gaya Aksial Maksimum } & \multicolumn{2}{l|}{ Gaya Aksial Maksimum } \\
\cline { 3 - 6 } & Tarik (+) kg & Tekan (-) kg & $\begin{array}{l}\text { Tarik } \\
\text { Akibat }\end{array}$ & $\begin{array}{l}\text { Tekan } \\
\text { Akibat }\end{array}$ \\
\hline Batang Bawah & 1 s.d. 10 & 7602,80 & $-975,33$ & COMB3 & ANGIN \\
\hline Batang Atas & 11 s.d. 20 & 586,51 & $-7898,75$ & ANGIN & COMB3 \\
\hline Batang Vertikal & 21 s.d. 29 & 340,18 & $-1806,25$ & ANGIN & COMB3 \\
\hline Batang Diagonal & 30 s.d. 37 & 2181,32 & $-370,64$ & COMB3 & ANGIN \\
\hline
\end{tabular}

c) Verifikasi Nilai Angka Keamanan Terhadap Gaya Aksial Tarik Terfaktor dan Aksial Tekan Terfaktor Batang

Tabel 4. Nilai angka keamanan struktur kuda-kuda baja Pratt siku ganda join jepit bentang $15 \mathrm{~m}$

\begin{tabular}{|l|l|l|l|l|l|l|l|}
\hline No. & Join & $\begin{array}{l}\text { Bentang } \\
(\mathrm{m})\end{array}$ & Profil 2L & $\begin{array}{l}\text { Klasifikasi } \\
\text { Batang }\end{array}$ & $\begin{array}{l}\text { Nilai Angka } \\
\text { Keamanan } \\
\text { Terhadap GA }\end{array}$ & $\begin{array}{l}\text { Nilai Angka } \\
\text { Keamanan } \\
\text { Terhadap ML }\end{array}$ & $\begin{array}{l}\text { Nilai } \\
\text { Angka } \\
\text { Keama } \\
\text { nan }\end{array}$ \\
\hline 1. & Jepit & 15 & 70.70 .7 & Bawah & 0,20 & 0,07 & 0,27 \\
\hline 2. & Jepit & 15 & 70.70 .7 & Atas & 0,27 & 0,05 & 0,32 \\
\hline 3. & Jepit & 15 & 70.70 .7 & Vertikal & 0,08 & 0,03 & 0,11 \\
\hline 4. & Jepit & 15 & 70.70 .7 & Diagonal & 0,06 & 0,02 & 0,08 \\
\hline
\end{tabular}

Tabel 4 menunjukkan nilai angka keamanan yang telah diverifikasi dengan SNI-031729-2002 tentang Tata Cara Perencanaan Struktur Baja untuk Bangunan Gedung. Nilai angka keamanan tersebut dijadikan acuan didalam mendesain ulang profil baja siku ganda. Desain ulang profil dilakukan sampai dengan mendekati batas nilai angka keamanan sama dengan 1 (satu). 


\section{KESIMPULAN}

Berdasarkan hasil perhitungan struktur kuda-kuda baja Pratt siku ganda dengan asumsi join sebagai sendi dan asumsi join sebagai jepit, diperoleh kesimpulan sebagai berikut :

1. Terdapat perbedaan nilai angka keamanan pada perhitungan struktur kuda-kuda baja dengan asumsi join sebagai sendi dan asumsi join sebagai jepit. Nilai angka keamanan batang bawah dan batang diagonal pada perhitungan asumsi join sebagai jepit selalu lebih besar dari nilai angka keamanan perhitungan asumsi join sebagai sendi. Sedangkan untuk nilai angka keamanan batang atas dan batang vertikal pada perhitungan asumsi join sebagai jepit selalu lebih kecil dari nilai angka keamanan perhitungan asumsi join sebagai sendi.

2. Tabel 5 menunjukkan besar selisih nilai angka keamanan kedua asumsi perhitungan. Besar selisih nilai angka keamanan meningkat seiring dengan bertambah panjangnya bentang struktur kuda-kuda baja Pratt siku ganda.

3. Verifikasi terhadap batang tarik struktur kuda-kuda baja Pratt siku ganda dengan asumsi join sebagai jepit menghasilkan nilai angka keamanan yang lebih besar dari asumsi join sebagai sendi.

4. Verifikasi terhadap batang tekan struktur kuda-kuda baja Pratt siku ganda dengan asumsi join sebagai jepit menghasilkan nilai angka keamanan yang lebih kecil dari asumsi join sebagai sendi.

5. Perhitungan struktur kuda-kuda baja Pratt siku ganda dapat dilakukan dengan mengasumsikan join sebagai sendi ataupun dengan mengasumsikan join sebagai jepit.

Tabel 5 Selisih nilai angka keamanan struktur kuda-kuda baja Pratt siku ganda antara asumsi join sebagai sendi dengan asumsi join sebagai jepit

\begin{tabular}{|c|c|l|c|c|}
\hline No & $\begin{array}{c}\text { Bentang } \\
(\mathrm{m})\end{array}$ & Klasifikasi Batang & $\begin{array}{c}\text { Selisih Nilai } \\
\text { Angka } \\
\text { Keamanan }\end{array}$ & Ket. \\
\hline 1 & 15 & Batang Bawah & $-0,11$ & $n_{a k j}>n_{a k s}$ \\
\hline 2 & 15 & Batang Atas & 0,04 & $n_{a k j}<n_{a k s}$ \\
\hline 3 & 15 & Batang Vertikal & 0,10 & $n_{a k j}<n_{a k s}$ \\
\hline
\end{tabular}




\begin{tabular}{|l|l|l|l|l|}
\hline 4 & 15 & Batang Diagonal & $-0,03$ & $n_{a k j}>n_{a k s}$ \\
\hline
\end{tabular}

\section{DAFTAR PUSTAKA}

Dep. Pemukiman dan Prasarana Wilayah. 2002, Tata Cara Perencanaan Struktur Baja Untuk Bangunan Gedung (SNI 03-1729-2002), Jakarta.

Dep. Pemukiman dan Prasarana Wilayah, 2002,. Metode, Spesifikasi dan Tata Cara (SNI03-1727-1989 Tata Cara Perencanaan Pembebanan Untuk Rumah dan Gedung). Jakarta:

ILT Learning., 2008, Belajar Sendiri SAP 2000 Versi 10. PT. Gramedia, Jakarta

Lambri, Bustraan Z., 2001, Daftar-Daftar Untuk Konstruksi Baja.: Pradnya Paramitha, Jakarta

Punmia, B. C. Jain, Ashok Kumar. Jain, Arun Kumar. , 1998, Comprehensive Design of Steel Structures. Fire Wall

Raguhpati, M. 1995, Design of Steel Structure.: Tata Mcgrow-Hill Publishing Company Limited, New York

Setiawan, Agus. 2008, Perencanaan Struktur Baja Dengan Metoda LFRD., Erlangga Jakarta

Schodek, Daniel L. Struktur. Bambang suryoatmono, penerjemah. Bandung: Eresco, 1991. 
